\title{
Autoimmune Phenomena in Patients with Solid Tumors
}

\author{
Ivanka S. Nenova ${ }^{1}$, Mariana Y. Valcheva ${ }^{1}$, Elina A. Beleva ${ }^{1}$, Dora Y.Tumbeva ${ }^{1}$, \\ Marianna P. Yaneva ${ }^{1}$, Emilia L. Rancheva ${ }^{2}$, Zhanet G. Grudeva-Popova' \\ ${ }^{1}$ Department of Clinical Oncology, Faculty of Medicine, Medical University of Plovdiv, Plovdiv, Bulgaria \\ ${ }^{2}$ Department of Accounting, Finance and Statistics, Agricultural University, Plovdiv, Bulgaria
}

\author{
Correspondence: I. Nenova, \\ Department of Clinical Oncol- \\ ogy, Faculty of Medicine, Medi- \\ cal University of Plovdiv, 15A \\ Vassil Aprilov Blvd., 4002, Plovdiv, \\ Bulgaria \\ E-mail: iv_nenova@abv.bg \\ Tel.: +359885612061 \\ Received: 15 Sep 2015 \\ Accepted: 20 June 2016 \\ Published Online: 8 Aug 2016 \\ Published: 30 Sep 2016
}

Key words: paraneoplastic syndromes, autoimmune phenomena, malignant tumors

Citation: Nenova IS, Valcheva MY, Beleva EA, Tumbeva DY, Yaneva MP, Rancheva EL, Grudeva-Popova ZG. Autoimmune Phenomena in Patients with Solid Tumors.

Folia Medica 2016;58(3);195-199 doi: 10.1515/folmed-2016-0026

\begin{abstract}
Introduction: Autoimmune disorders have been documented in solid tumors and malignant hematological disorders. They are very common and well studied in lymphomas which are associated with immune imbalance. They are less common in solid tumors and are categorized as paraneoplastic syndromes with unclear pathogenesis.
\end{abstract}

Aim: The aim of the present study was to find the frequency of autoimmune phenomena in solid tumors of various origin, location and status of the tumor.

Patients and methods: Between 2000 and 2014 we studied 1083 patients with solid tumors that were diagnosed and treated in St George University Hospital, Plovdiv.

Results: We found higher incidence of these phenomena in prostate and ovarian carcinomas (9.01\% and 5.6\%, respectively) than in other solid tumors. Their distribution by type of autoimmune disease showed that vasculitis, polyneuritis and autoimmune hemolytic anemia have the highest frequency of all. Immune thrombocytopenia, seronegative arthritis, psoriasis, polymyositis are less commonly documented. The autoimmune paraneoplastic phenomena manifest themselves metachronously, less commonly synchronously, with the tumor. In most cases, their clinical manifestation is a progressive disease or metastatic malignant disorder which respond favourably to therapy.

Conclusion: Paraneoplastic autoimmune phenomena are found very commonly in prostate and ovarian carcinomas. They occur in the course of the evolvement of neoplasm and can regress with medicamentous or surgical treatment of the malignoma.

\section{INTRODUCTION}

Paraneoplastic syndromes, associated with the distant effect of humoral factors produced by the tumour, are known to develop concomitantly with malignant tumors. The autoimmune syndromes are relatively rare paraneoplastic events. ${ }^{1,2}$ They are more common and better studied in lymphomas. ${ }^{3,4}$ There are only single reports of these in solid tumors.

The aim of the present study was to find the frequency of autoimmune phenomena in solid tumors of various origin, location and status of the tumor.

\section{PATIENTS AND METHODS}

The present prospective study recruited 1083 patients diagnosed and treated in St George University Hospital in Plovdiv between 2010 and 2014.
The patient distribution by type of solid tumour was as follows: breast carcinoma - 240, colon carcinoma - 240, ovarian carcinoma - 71, prostate carcinoma - 55, lung carcinoma - 95 and others.

Patients with lymphomas were excluded from the study.

The diagnosis of autoimmune paraneoplastic phenomena is based on the following laboratory tests: for autoimmune hemolytic anemia - Coombs test (direct and indirect) and serological evidence of antierythrocyte antibodies; for immune thrombocytopenia - the platelet survival test and sequestration of platelets using chromium-51; for other autoimmune syndromes we studied the antinuclear antibodies, the rheumatoid factor, the serum complement $\mathrm{C} 3$, the lupus anticoagulant, the antineutrophil cytoplasmic antibodies, capillaroscopy and some other indicators 
of autoimmune aggression.

In the statistical analysis we determined the indicators of relative proportion. The structure of the patients' groups and the types of autoimmune complications are presented graphically.

\section{RESULTS}

We found an incidence of $1.29 \%$ for the autoimmune paraneoplastic syndromes in malignant solid tumors. The distribution by type of autoimmune disease shows high frequency of vasculitis (3/14 cases), autoimmune hemolytic anemias (3/14) and polyneuritis (3/14). Immune thrombocytopenia, seronegative arthritis, psoriasis, polymyositis are less frequently recognised.

We found higher incidence of autoimmune phenomena in prostate carcinoma $(9.09 \%)$ and ovarian carcinoma (5.6\%) than in other solid tumors (Fig. 1). Autoimmune paraneoplastic phenomena may occur metachronously (with some time elapsing between diagnosis of malignancy and onset of autoimmune complications, may range between 6 months to 6 years), and less rarely synchronously with the malignancy (Table 1). In a female patient we found autoimmune thrombocytopenia 22 years after successful treatment of ovarian cancer. This interval of time, and lack of data on recurrence of carcinoma give us grounds to assume that it is more likely to have a combination of a primary autoimmune disease with neoplasm, rather than paraneoplastic syndrome.

In most cases the paraneoplastic phenomena cooccur with a progressive disease or a metastatic disease $(9 / 14)$ and respond favourably to therapy.

Table 1. Clinical characteristic of patients

\begin{tabular}{|c|c|c|c|c|}
\hline لْ & Malignancy & Status of the tumor & $\begin{array}{l}\text { Autoimmune } \\
\text { paraneoplastic } \\
\text { syndrome }\end{array}$ & $\begin{array}{c}\text { Interval between diagnosis of } \\
\text { tumour and paraneoplastic } \\
\text { syndrome }\end{array}$ \\
\hline 1 & Prostate carcinoma & Bone metastasis & Polymyositis & Five years after carcinoma \\
\hline 2 & Prostate carcinoma & Bone metastasis & Vasculitis & Three years after carcinoma \\
\hline 3 & Prostate carcinoma & T3N0M0 & Polyneuritis & Six years after carcinoma \\
\hline 4 & Prostate carcinoma & Unspecified & Hemolytic anemia & Synchronous with carcinoma \\
\hline 5 & Prostate carcinoma & Unspecified & Thrombocytopenia & Synchronous with carcinoma \\
\hline 6 & Ovarian carcinoma & Peritoneal metastases & Vasculitis & Six months after carcinoma \\
\hline 7 & Ovarian carcinoma & Peritoneal metastases & Psoriasis & Synchronous with carcinoma \\
\hline 8 & $\begin{array}{l}\text { Ovarian and gastric } \\
\text { carcinoma }\end{array}$ & Hepatic metastasis & Polyneuritis & Six months after carcinoma \\
\hline 9 & Ovarian carcinoma & Recurrence & Hemolytic anemia & Two years after carcinoma \\
\hline 10 & $\begin{array}{l}\text { Carcinoma of the } \\
\text { head/neck }\end{array}$ & Lung metastases & Arthritis & One year after carcinoma \\
\hline 11 & $\begin{array}{l}\text { Head / Neck } \\
\text { carcinoma }\end{array}$ & T3N0Mx* & Polyneuritis & Six months after carcinoma \\
\hline 12 & Breast carcinoma & $\begin{array}{l}\text { Lymph nodes } \\
\text { metastasis }\end{array}$ & Vasculitis & One year after carcinoma \\
\hline 13 & $\begin{array}{l}\text { Pulmonary } \\
\text { carcinoma }\end{array}$ & TxNxM1* & Arthropathy & Six months after carcinoma \\
\hline 14 & Colon-cancer & Unspecified & Anemia & Synchronous with carcinoma \\
\hline
\end{tabular}

* Defined according to the TNM staging system (Union for International Cancer Control.) Gospodarowicz MK et al. Cancer 2004;100:1-5. 


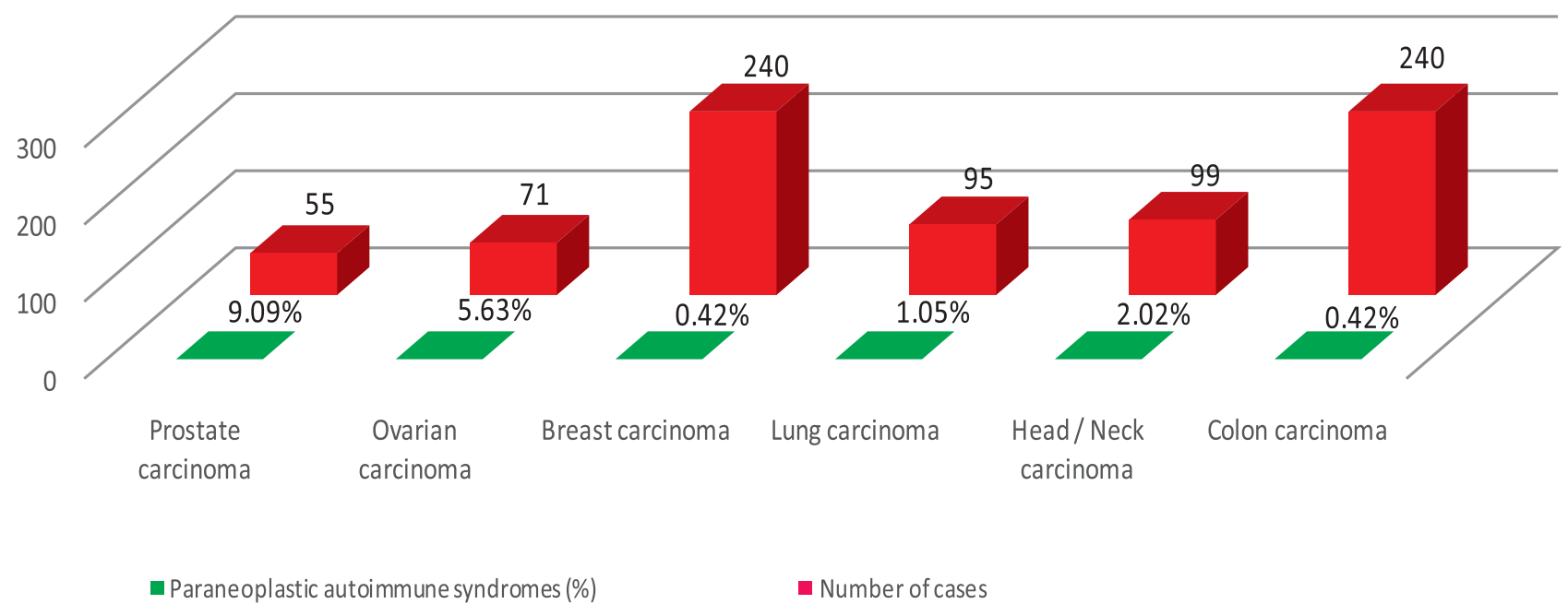

Figure 1. Number of cases and percentages of paraneoplastic autoimmune syndromes in various solid tumours.

\section{DISCUSSION}

The first report of an autoimmune disorder appearing as a debut manifestation of a malignant tumour was made in $1916 .{ }^{5}$ A lot of evidence has since been accumulated for a reciprocal interactive relationship between tumour and autoimmune disorders.

On the one hand, some autoimmune disorders have been found to have an increased risk of occurrence of neoplasms, usually after a prolonged period of time. ${ }^{6,7}$ Non-Hodgkin's lymphomas is very often found in patients with Sjögren's syndrome. Neoplastic hematological diseases and malignant tumors of the gastrointestinal tract develop in celiac disease, Crohn's disease and in chronic ulcerative hemorrhagic colitis. ${ }^{8}$ It has been found that $8 \%$ of vasculitis patients develop cancer. ${ }^{5}$

On the other hand, malignant tumors, and sometimes antineoplastic therapy, trigger immune dysregulation and create conditions for autoimmune complications. The immunosuppressive therapy has been considered to play a role as etiologic noxa for cancer. $^{9}$

It is believed that a key moment in the pathogenesis of autoimmune and malignant disorders is the inhibition of apoptosis. ${ }^{10}$ In tumors this leads to induction of anti DNA antibodies and inhibition of $\mathrm{T}$ cell-protective function. Along with this pseudo-autoimmune status the tumors induce immunosuppression by IL-10, TGF- $\beta$, VEGF, modulate the function of macrophages and dendritic cells, which boosts the generation of metastases. ${ }^{10}$
Some genetic disorders have been associated with the disrupted process of apoptosis. The malignant phenotype is associated with overexpression of Bcl-2 oncogene with anti-apoptosis effect, as well as a mutation of p-53 tumor suppressor gene that supports genome stability. Mutant Fas gene (inducer of apoptosis) is the reason for the occurrence of lymphomas. ${ }^{11}$ In apoptosis-inducing PTEN genes there are mutated variants that predispose to the development of cancer. ${ }^{12}$ The connecting link in the genetics of autoimmune diseases and tumors are the genes for glutathione $\mathrm{S}$ transferase. They encode enzymes that facilitate the metabolism of potentially toxic components. The mutations in these genes play a key role not only in carcinomas, but also in lupus erythematosus, rheumatoid arthritis and the myelodysplastic syndrome. Studying them makes it possible to identify genotypes with a higher risk for prostate cancer and carcinoma of the breast. $^{12}$

Criteria have been sought to differentiate the idiopathic autoimmune diseases from autoimmune paraneoplastic phenomena, emphasizing some atypical features (age, laboratory data). ${ }^{5}$ The most salient difference is the chronology of their appearance. The autoimmune paraneoplastic phenomena (unlike primary autoimmune diseases) are characterized by either a synchronous or metachronous development (after) with the primary tumor.

The auto-aggression is directed against the socalled tumor associated antigens - oncoproteins (c-myc), antigens encoded by mutated 53 tumor 
suppressor gene, differentiating antigens, cell surface receptor (HER), onconeural antigens, cancer/testis antigens. Anti-DNA antibodies are the commonest diagnostic findings - 24\% of neoplasms and 50\% of breast carcinomas. ${ }^{8,9}$

Autoimmune paraneoplastic phenomena have been demonstrated in various tumours without any specificity. They occur relatively more frequently in ovarian and prostate carcinomas. Autoimmune hemolytic anemia is more common in renal cell carcinoma and Kaposi sarcoma. ${ }^{13}$

There is no consensus in the literature regarding the potential diagnostic and prognostic value of autoimmune phenomena. ${ }^{12,14}$ Some researchers have found them to precede immediately the diagnosis of tumors which is not supported by our study.

\section{CONCLUSION}

Paraneoplastic autoimmune phenomena were found in $1.29 \%$ of the cases of malignant solid tumors. They occur more frequently in carcinomas of the prostate and ovaries. Clinically, they manifest themselves in progression of the malignant tumor. They respond favourably to drug therapy or surgical treatment of the malignomas.

\section{REFERENCES}

1. Andras C, Csiki Z, Ponyi A, et al. Paraneoplastic rheumatic syndromes. Rheumatol Int 2006;26(5):376-82.

2. Chakravarty E, Genovese MC. Rheumatic syndromes associated with malignancy. Curr Opin Rheumatol 2003; 15(1):35-43.

3. Zintzaras E, Voulgarelis M, Moutsopoulos HM.
The risk of lymphoma development in autoimmune diseases: a meta-analysis. Arch Intern Med 2005;165(20):2337-44.

4. Jones S. Autoimmune disorders and malignant lymphoma. Cancer 1973;31(5):1092-8.

5. Racanelli V, Prette M, Minoia K, et al. Rheumatic disorders as paraneoplastic syndromes. Autoimmunity review 2008;7(5):352-8.

6. Bernatsky S, Ramsey-Goldman R, Clarke A. Malignancy and autoimmunity. Curr Opin Rheumatol 2006;18(2):129-34.

7. Kiss E, Kovacs L, Szodoray P. Malignancies in systemic lupus erythematosus. Autoimmun Rev 2010;9(4):195-9.

8. Shakra M, Buskila D, Ehrenfeld M, et al. Cancer and autoimmunity: autoimmune and rheumatic features in patients with malignancies. Am Rheum Dis 2001;60(5):433-440.

9. Achenza S, Selmi C. Autoimmunity and cancer. Asian Pac J Cancer Prev 2012;13:29-40.

10. Kim R, Emi M, Tanabe K. Cancer immunosuppression and autoimmune disease: beyond immunosuppressive networks for tumour immunity. Immunology 2006;119(2):254-64.

11. Malaguarnera M, Cristaldi E, Romano G, Malaguarnera L. Autoimmunity in the elderly: Implications for cancer. J Cancer Res Ther 2012;8(4):520-7.

12. Volkers N. Do autoimmune diseases raise the risk of cancer? J Natl Cancer Inst 1999;91:1992-3.

13.Puthenparambil J, Lechner K, Korneg G. Autoimmune hemolytic anemia as a paraneoplastic phenomenon in solid tumors: a critical analysis of 52 cases reported in the literature. Wien Klin Wochenschr 2010;122:229-36.

14. Anhalt GJ. Paraneoplastic Pemphigus. J Invest Dermatol Symp Proc 2004;9:29-33. 


\title{
Аутоиммунные синдромы у пациентов с солидными опухолями
}

\author{
Иванка С. Ненова ${ }^{1}$, Марияна Й. Вылчева ${ }^{1}$, Элина А. Белева ${ }^{1}$, Дора Й. Тумбева ${ }^{1}$, Мариа- \\ на П. Янчева ${ }^{1}$, Эмилия Л. Ранчева², Жанет Г. Грудева -Попова ${ }^{1}$ \\ ${ }^{1}$ Кафедра клинической онкологии, Медицинский факультет, Пловдивский медицинский университет,. Пловдив, Болга- \\ рия \\ 2 Кафедра бухгалтерского учета, финансов и статистики, Аграрный университет, Пловдив, Болгария
}

\begin{abstract}
Для корреспонденции: Иванка Ненова, Кафедра клинической онкологии, Медицинский факультет, Пловдивский медицинский университет, Пловдив, Болгария E-mail: iv_nenova@abv.bg Тел: +359885612061
\end{abstract}

Дата получения: 15.09.2015 г. Дата приемки: 20.06.2016 г. Дата онлайн публикации: 08.08.2016 г.

Дата публикации: 30.09 .2016 г.

\section{Ключевые слова:}

паранеопластические синдромы, аутоиммунные синдромы, злокачественные опухоли

Цитаты: Ненова И.С., Вылчева М.Й., Белева Е.А., Тумбева Д.Й., Янева М.П., Ранчева Е.Л., Грудева - Попова Ж.Г. Аутоиммунные синдромы у пациентов с солидными опухолями.

Журнал "Folia Medica" 2016;58(3);195-199 doi: 10.1515/folmed-2016-0026
Наличие аутоиммунных нарушений документировано у пациентов с солидными опухолями и злокачественными гематологическими нарушениями. Они часто встречаются и хорошо исследованы при наличии лимфом, которые связаны с иммунным дисбалансом. При наличии солидных опухолей встречаются реже и включены в категорию паранеопластических синдромов с неясным патогенезом.

Цель: Целью настоящего исследования было определение частоты возникновения аутоиммунных синдромов при наличии солидных опухолей разного происхождения, с разной локализацией и статусом.

Результаты: Нами установлена более высокая степень проявления этих синдромов при наличии карцинома простаты и овариального карцинома $(9.01 \%$ и 5.6\%, соответственно), чем при наличии иных солидных опухолей. Их распространение в зависимости от типа аутоиммунного заболевания показывает, что васкулит, полиневрит и аутоиммунная гемолитическая анемия встречаются чаще всего. Наличие иммунной тромбоцитопении, серонегативного артрита, псориаза, полимиозита документировано реже. Аутоиммунные паранеопластические синдромы проявляются в метахроническом ритме, реже в синхронном ритме с опухолью. В большинстве случаев их клиническое проявление связано с прогрессивным заболеванием или метастатическим злокачественным нарушением, на которое оказывает хорошее влияние терапия.

Заключение: Паранеопластические аутоиммунные синдромы очень часто встречаются при наличии карцинома простаты и овариального карцинома. Они проявляются в ходе развития новой опухоли и могут регрессировать в результате медикаментозного или оперативного лечения злокачественной опухоли. 